\title{
An Analysis of Phonological Processes Involved in Spoken English of Hong Kong Primary Pre-service Teachers
}

CYNTHIA B. LEUNG

University of South Florida St. Petersburg

ALEJANDRO E. BRICE

University of South Florida St. Petersburg

\section{Bio Data:}

Dr. Cynthia B. Leung is an Associate Professor of Literacy Education at the University of South Florida St. Petersburg. Her areas of research are TESOL for Asian learners, early literacy, and vocabulary development and assessment.

Dr. Alejandro E. Brice is an Associate Professor at the University of South Florida St. Petersburg. His research has focused on transference or interference between two languages in the areas of phonetics, phonology, semantics, and pragmatics.

\begin{abstract}
This study investigated the English phonological processes and speech articulation of adult Cantonese-English speakers residing in Hong Kong. The Phonology Test for Cantonese Speakers of English (PTCSE) was developed to assess English articulation and phonological processes of native speakers of Cantonese. Data from 37 adult participants, analyzed descriptively, yielded a total of 466 phonological process deviations. Two syllable words presented the most difficulty, followed by three and single syllable words. Results indicated this group of Cantonese-English speaking participants displayed a wide variety of articulatory patterns, some of which were not evidenced by the literature. Phonological processes noted in this study included: (a) stopping; (b) fronting; (c) deaffrication; (d) gliding; (e) devoicing; (f) lip rounding; (g) backing; (h) affrication; (i) voicing; (j) pre-vocalic singleton omission; (k) post-vocalic singleton omission; (l) consonant sequence reduction; (m) vowel deviations; and, (n) vowel additions. Five suggested instructional strategies focusing on speech production are provided.
\end{abstract}

Keywords: Language Testing, Phonological Processes, English in Hong Kong, Oral Language, Articulation, Phonology, Cantonese Language Interference 


\section{Introduction}

This paper focuses on the articulation and phonological processes that occur in the English spoken by Cantonese L1 speakers and reports on the development of a phonology test to identify English phonological processes of Cantonese speakers. Specifically, we focus on the English spoken by primary pre-service teachers studying to be teachers of English in Hong Kong schools.

Phonological processes are rules used to simplify pronunciation of words in a language. Use of phonological processes is typically discontinued by the time the child reaches a certain developmental age. The ages by which the child discontinues the use of phonological processes has been shown to vary by languages (So \& Dodd, 1995). Adults, however, may not overcome this developmental progression and continue to exhibit phonological process deviations (Selinker \&Lamendella, 1980; Wei 2008). These phonological process simplifications may include syllable structure processes, substitution processes, and/or assimilation processes. Within each of these overall classifications are numerous specific phonological process deviations; such as, epenthesis, final consonant deletion, cluster reduction under syllable structure processes; stopping, fronting, backing under substitution processes; and, voicing, labial assimilation, alveolar assimilation under assimilation processes.

Phonological processes are natural deviations that occur as one is developing a language, but if they persist, in children they can be a sign of a phonological disorder. Some sounds of a language are particularly difficult for children and learners of a second or other language to articulate. Children learning English may have difficulty saying certain sounds because their vocal apparatus may not have developed to the extent necessary to produce the appropriate articulations. Learners of English as a second or other language may encounter problems in pronunciation because of contrastive differences between English and their first language (Chan \& Li, 2000).

English-speaking children commonly replace a more difficult sound with an easier sound, shorten words, and change word structure as they acquire and master the speech sounds of English. By age 3, most children have mastered articulation of English to the extent they no longer use the following phonological processes in their speech: (a) weak syllable deletion (omission of an unstressed syllable, i.e., tephone for telephone); (b) final consonant deletion (omission of the last consonant of a word, i.e. boo for book); (c) consonant assimilation (one consonant in a word substituted and influenced by a second consonant, i.e.,beb for bed); (d) reduplication (repetition of a syllable forming a multisyllabic form of the word, i.e., baba for bottle; and (e) velar fronting $(/ \mathrm{k} /$ and $/ \mathrm{g} /$ substituted for sounds produced anteriorly, i.e. tookie for cookie) (Merkel-Piccini, 2001; Nicolosi, Harryman, \& Kresheck, 2004; Williamson, 2010).

Some phonological processes that continue in English-speaking children's speech after 3 years of age include: (a) cluster reduction (omission of a consonant in a cluster or sequence, i.e.,back for black); (b) epenthesis (insertion of a vowel in a word, i.e., buhlack for black); (c) gliding (/r/ and /1/ replaced by /w/, i.e., wun for run); (d) vowelization (a consonant replaced by a vowel, i.e. boyd for bird); and, (e) stopping (a fricative replaced by a stop, i.e., toup for soup). Most English speaking 
children resolve these processes by age 7, but stopping, gliding, and cluster reduction are persistent and may continue beyond that age (Merkel-Piccini, 2001; Nicolosi, Harryman, \& Kresheck 2004; Williamson, 2010).

\section{Cantonese and English Phonemic Differences}

Cantonese speakers of English may encounter difficulties articulating certain sounds of English because of articulation differences between Cantonese and English. English has 24 consonants, while Cantonese has 19 (Chan \& Li, 2000). Cantonese has three nasals $(/ \mathrm{m}, \mathrm{n}, \mathrm{y} /)$, six stops $(/ \mathrm{p}, \mathrm{b}, \mathrm{t}, \mathrm{d}, \mathrm{k}, \mathrm{g} /)$, three fricatives $(/ \mathrm{f} / \mathrm{,} / \mathrm{s} /$, glottal $/ \mathrm{h} /)$, two affricates $\left(/ \mathrm{t} \int, \mathrm{d}_{3} /\right)$, two velar stops $(/ \mathrm{kw}, \mathrm{kwh} /)$, two glides $(/ \mathrm{w}, \mathrm{j} /)$, and one lateral $(/ 1 /)$. Six consonants can occur in syllable final positions $(/ m, n, y, p, t$, k/) (Chan \& Li, 2000; Chen, Anderson, Li, Hao, Wu, \& Shu, 2004; Hung, 2002; Law \&So, 2006). Both English and Cantonese have six plosive stops (/p, b, t, d, k, g); however, in English / b, d, g/ are voiced, while in Cantonese all plosive stops are voiceless (Chan \& Li, 2000; Hung 2002). In Cantonese, /p, t, k/ are aspirated, and only voiceless stops $(/ \mathrm{p}, \mathrm{t}, \mathrm{k} /)$ can occur in the final position of words (Chan \& Li, 2000). Cantonese fricatives are all voiceless (Hung 2002).

Cantonese has fewer vowel phonemes than English, eight compared to twelve. English has seven short vowels $(/ \mathrm{I}, \mathrm{e}, \mathfrak{x}, v, \mathrm{p}, \Lambda$, / /) and five long vowels $(/ \mathrm{i}$, $\mathrm{u}, \mathrm{o}, \mathrm{a}, 3 /$ ), while Cantonese only has one long vowel, long /a/, and seven short vowels (/i, e, y, u, o, æ, a/). Cantonese does not have the schwa /ə/, which is the most frequent vowel sound in English (Chan \& Li, 2000). Both languages have a number of diphthongs (eight in English and ten in Cantonese), but the final vowels of the diphthongs differ in the two languages (/ə, I, $v /$ in English and /i, u, y/ in Cantonese).

English has a complex syllable structure involving beginning and ending consonant clusters. English can include three consonant clusters before a vowel (CCCV in the initial position of a word) and four consonant clusters after a vowel (VCCCC in the final position of a word). The word strengths exemplifies this English feature (CCCVCCCC). By contrast, Cantonese has no consonant clusters, and the maximum syllable structure is CVC. Cantonese syllables may consist of $\mathrm{V}, \mathrm{CV}, \mathrm{VC}$, CVC, CVV, or single nasal sounds (Law \& So, 2006).

It has been noted children acquire Cantonese sounds earlier than children acquire English sounds (So \& Zhou, 1998). Phonemes acquired early in Cantonese include nasals, glides, and front stops (So \& Dodd,1995). Cantonese-speaking children acquire vowels and tones by two to three years of age (So \& Dodd, 1995; So \& Zhou, 1998). Children typically acquire all Cantonese consonants by age 5 (So \& Zhou, 1998). Cantonese children use unaspirated voiceless stops, while Englishspeaking children use aspirated voiceless stops (So \& Dodd, 1995). Few phonological process deviations in Cantonese are made after age 4 (So \& Dodd, 1995), and most phonemes are acquired by age 5 (Law \& So, 2006). In English, the load of word meaning is conveyed through consonants, vowels, syllable structure, and stress (So \& Dodd, 1995). In contrast, Cantonese is a tonal language, and tones carry a heavy load in word meaning. In sum, Cantonese speakers may find it difficult to acquire English pronunciation because of the structural differences between the two languages (Chan \& Li, 2000; So \& Dodd, 1995). 


\section{Phonological Processes of Cantonese Speakers of English}

Cantonese has a smaller inventory of consonant contrasts when compared to English; therefore, when learning English, Cantonese speakers may often substitute the following sounds: (a) $/$ f $/$ for $/ \theta /$; (b) $/$ d / for $/ \partial /$; (c) $/ w /$, $/$ f $/$ for $/ v /$; (d) $/ \mathrm{t} /$, /f/ for $/ \theta /$, /ð/; (e) $/ \mathrm{f} /$ for $/ 3 / ;$ (f) $/ \mathrm{s} /$ for $/ \mathrm{J} / ;$ (g) $/ \mathrm{ts} /$ for $/ \mathrm{t} / ;$ (h) $/ \mathrm{dz} /$ for $/ \mathrm{d} 3 /$; (i) / l/ for / $\mathrm{V}$; (j) / l/ for /n/; and, (k) / w/ for / J (So \& Dodd 1995; So \& Zhou 1998). Substitutions are phonological processes involving systemic simplification, with one speech sound replacing another (Lahey, 1988). Cantonese speakers of English may substitute Cantonese phonemes for English phonemes that do not exist in their first language. Fronting, when a posterior sound is replaced by a more anterior sound, and stopping, when a fricative consonant is substituted with a stop consonant, are common types of substitutions (Lahey, 1988). Assimilation is another simplification process that occurs when one sound is replaced by another due to the influence of other sounds in a word (Lahey, 1988). Studies of English phonology spoken by Cantonese speakers in Hong Kong have identified a number of substitutions or changes in articulation when English is spoken by Cantonese L1 speakers (Chan \& Li, 2000; Hung, 2000; Shibbard, 2004).In Table 1 we identify the phonological processes involved in the substitutions and assimilations found in these studies.

Table 1

Typical Cantonese-English Corresponding Phonological Processes

\begin{tabular}{|c|c|c|c|c|c|c|}
\hline $\begin{array}{l}\text { Substitution } \\
\text { Change }\end{array}$ & Stopping & Fronting & Deaffrication & Gliding & Devoicing & $\begin{array}{l}\text { Lip } \\
\text { rounding }\end{array}$ \\
\hline$/ \theta /->/ t /$ & 1 & & & & & \\
\hline$/ \theta /->/ f /$ & & 3 & & & & \\
\hline $\begin{array}{l}/ \text { // ->/t/, } \\
/ \mathrm{d} /\end{array}$ & 1 & & & & & \\
\hline /ð/ -> /f/ & & 1 & & & 1 & \\
\hline$/ \mathrm{v} / \mathrm{-}->/ \mathrm{f} /$ & & & & & 3 & \\
\hline$/ \mathrm{v} / \mathrm{-} / \mathrm{w} /$ & & & & 3 & & 3 \\
\hline$/ 3 /->/ f /$ & & 1 & & & & \\
\hline$/ \mathrm{J} /->/ \mathrm{s} /$ & & 3 & & & & \\
\hline$/ \mathrm{t} \int /->/ \mathrm{ts} /$ & & 1 & 1 & & & \\
\hline $\begin{array}{l}/ d_{3} /-> \\
/ d z /\end{array}$ & & 1 & 1 & & & \\
\hline $\begin{array}{l}/ \mathrm{V} / \mathrm{-} / \mathrm{l} / \mathrm{s} \\
/ \mathrm{w} /\end{array}$ & & & & 1,2 & & \\
\hline
\end{tabular}




\begin{tabular}{|l|l|l|l|l|l|l|}
\hline$/ \mathrm{n} /->/ 1 /$ & & & & 1 & & \\
\hline
\end{tabular}

1. Chan and Li (2000); 2. Hung (2000); 3. Shibbard (2004)

As a consequence of Cantonese having few consonant clusters, Cantonese speakers of English may delete one or more of the consonants in both word initial and word final positions (initial and final consonant deletion) and/or add an additional sound (epenthesis) in the word (e.g., blanket becomes buh-lanket). Cantonese speakers also tend not to differentiate between English long and short vowels (e.g., /i/ vs. /I/; /u/ vs. / /; and, /o/ vs. /p/) (So \& Dodd, 1995; So \& Zhou, 1998). In Table 2 we summarize Cantonese to English vowel substitutions previously identified by researchers (Chan \& Li, 2000; Hensman, 1969; Hung, 2000; Ruikuo, 2005; So \& Dodd, 1995; So \& Zhou, 1998).

Table 2

Typical Cantonese-English Vowel Substitutions

\begin{tabular}{|c|c|c|c|c|c|c|}
\hline $\begin{array}{l}\text { /I / } \\
\text { (hidd) }\end{array}$ & $\begin{array}{l}\text { /u/ } \\
\text { (boot) }\end{array}$ & $\begin{array}{l}\text { /a/ } \\
\text { (saw) }\end{array}$ & /i/ (see) & $\begin{array}{l}\text { /ae/ } \\
\text { (cat) }\end{array}$ & $\begin{array}{l}/ \partial / \\
\text { (ago) }\end{array}$ & $\begin{array}{l}\text { /o/ } \\
\text { (bought) }\end{array}$ \\
\hline $\begin{array}{l}\text { /I/-> } \\
/ \mathrm{e} / \\
\text { (play) } 3\end{array}$ & $\begin{array}{l}/ \mathrm{u} /- \\
>/ \mathrm{o} / \\
\text { (bought) } \\
1\end{array}$ & $\begin{array}{l}/ \mathrm{a} /- \\
>/ \mathrm{o} / \\
\text { (bought) } \\
2\end{array}$ & $\begin{array}{l}\text { /i/-> } \\
/ \mathrm{I} / \text { (hid) } \\
1,5,6\end{array}$ & $\begin{array}{l}/ a e /-> \\
\text { /e/ } \\
\text { (play) } 2\end{array}$ & $\begin{array}{l}/ \partial /-> \\
/ \mathrm{e} / \\
\text { (play) } 4\end{array}$ & $\begin{array}{l}/ \mathrm{o} /- \\
>/ \mathrm{p} / \\
\text { (rock) } 5, \\
6\end{array}$ \\
\hline $\begin{array}{l}/ \mathrm{I} /- \\
>/ \varepsilon / \\
\text { (head) } 3\end{array}$ & $\begin{array}{l}\mathrm{u} /- \\
>/ \mathrm{v} / \\
(\text { foot) } 1, \\
5,6\end{array}$ & & $\begin{array}{l}/ \mathrm{i} /-> \\
\text { /ei/ } \\
\text { (lane) } 4\end{array}$ & $\begin{array}{l}/ \mathrm{ae} /- \\
>/ \mathrm{ov} / \\
(\mathrm{go}) 2\end{array}$ & $\begin{array}{l}\text { /o/ -> } \\
/ \text { i/ } \\
\text { (see) } 2\end{array}$ & \\
\hline
\end{tabular}

1. Chan and Li (2000); 2. Hensman (1969); 3. Hung (2000); 4. Ruikuo (2005); 5. So and Dodd (1995); 6. So and Zhou (1998)

\section{Methodology}

The present study aims to investigate the phonological processes and speech articulation of adult Cantonese-English speakers residing in Hong Kong who are primary pre-service teachers of English. It is believed that several factors may affect their English pronunciation: Cantonese interference, lack of knowledge of English phonological constraints, logographic writing background, and the influence of Received Pronunciation (RP, or British English) vs. American English dialects spoken in Hong Kong (Kirkpatrick, 2007). The study is guided by the following research question: After completing a 4-week unit of study on English phonology, which phonological processes will still persist in the pronunciation of English one, two, and three syllable words by Cantonese-English speakers in Hong Kong? 


\section{Participants}

The data were obtained from 37 adult native speakers of Cantonese in Hong Kong, 31 female and 6 male. Participants were in their first year of study in a primary teacher certification program at the Hong Kong Institute of Education. Teaching certification for these subjects included certification to teach English at the primary level. Prior to university enrollment, they attended English-medium schools for 13 years, 6 years in primary school and 7 years in secondary school. The average amount of time spent in English studies during these 13 years was 7 to 8 hours per week. Their exposure to English could be characterized as typical of the experiences of students attending English-medium schools at the time.

Their proficiency in English in terms of the Interagency Language Roundtable Scale (ILR, 2010) could be characterized as Level 3 (General Professional Proficiency). The ILR scale consists of an 11 point scale with plus scores per level: (a) Speaking 0 (No Proficiency); (b) Speaking 0+ (Memorized Proficiency); (c) Speaking 1 (Elementary Proficiency); (d) Speaking 1+ (Elementary Proficiency, Plus); (e) Speaking 2 (Limited Working Proficiency); (f) Speaking 2+ (Limited Working Proficiency, Plus); (g) Speaking 3 (General Professional Proficiency); (h) Speaking 3+ (General Professional Proficiency, Plus); (i) Speaking 4 (Advanced Professional Proficiency); (j) Speaking 4+ (Advanced Professional Proficiency, Plus); (k) Speaking 5 (Functionally Native Proficiency).

All participants passed the Hong Kong Advanced Supplementary Level Examination (HKASLE), including the English AS level examination (UE). At the time of data collection, the participants were enrolled in an English course that included the study of English phonetics and phonology.

\section{Data Collection}

Participants individually tape recorded their pronunciation of 40 stimulus items, phonetic transcriptions of English words using the International Phonetic Alphabet (IPA). Data consists of pronunciations from phonetic transcriptions of: (a) 17 onesyllable words; (b) 12 two-syllable words; and (c) 11 multisyllabic words.

\section{Development of the Phonology Test for Cantonese Speakers of English (PTCSE)}

ThePhonology Test for Cantonese Speakers of English (PTCSE) (see Appendix B)is a research tool created by two university researchers that assesses English articulation and phonology skills of Hong Kong residents. The PTCSE assesses English initial and final consonants and vowels. Phonetic transcriptions in Received Pronunciation (RP) English and American English for stimulus items were obtained from Better English Pronunciation (O'Connor 1969), a classic work on English Pronunciation. Participants pronounced the English words by reading the phonetic transcriptions. Establishing content validity for the PTCSE was achieved by the following means.

1. A comprehensive and systematic review of the literature of English and Chinese articulation and phonology was conducted. The literature (Chan \& Li, 2000; Chen, Anderson, Hao, Wu, \& Shu, 2004; Hensman, 1969; Hung, 2002; Ruikuo, 2005; Shibbard, 2004; So \& Dodd, 1995; So \& Zhou, 1998) revealed that the following 13 phonological patterns were highly occurring in Chinese speakers of English: (a) Gliding; (b) Lip rounding; (c) Vowel deviations; (c) Cluster reduction; (c) Fronting; 
(d) Affrication; (e) Devoicing; (f) Post-vocalic singleton omission; (g) Stopping; (h) Voicing; (i) Backing; (j) Pre-vocalic singleton; and (k) Deaffrication.

2. Two fluent and native and native-like speakers of English reviewed the items for standard RP and American English pronunciation. The speakers transcribed the stimuli using narrow and broad transcription over 10 meetings (one hour sessions each). One hundred percent consensus or agreement was achieved during these sessions regarding the transcriptions.

3. In preparing the test format, it was decided a priori that each individual behavior (item) should possess the same weight of importance. Practically this meant that no single articulation production or phonological process in and of itselfshould suggest a typical pronunciation or deviation. The end result was that articulation production would be based upon the individual phonological process and overall percentage of occurrence (POC) scores.

4. Preliminary field testing of items was performed with 37 speakers of English in Hong Kong. A classical item analysis model (Crocker \& Algina, 1986), involving comparison of the individual phonological raw deviations to the total possible number of deviations, was used (i.e., an item-to-test correlation). A Pearson correlation of $\mathrm{r}=0.49$ was achieved. A one sided t-test indicated significance $[\mathrm{t}(13)=1.89 ; \mathrm{p}=0.04]$. Effect size indicated a shared variance of $24 \%\left(\mathrm{R}^{2}=0.24\right)$. Cohen's $(1988)$ criteria (i.e., small $=.10-.29$, medium $=.30-.49$, large $>.50)$ indicated this effect size to be small. As expected no one phonological process would indicate overall intelligibility as demonstrated by the effect size scores; however, the item-to-test correlation indicates a significant relationship. Thus, the separate phonological processes and overall test seem to be justified.

\section{Data Analysis}

The data were transcribed by the first author, who has expertise in second language acquisition, Chinese language development, English teaching, phonetics, and phonology. Twenty percent of all the stimuli were analyzed for inter-rater reliability by a linguist proficient in Cantonese and English. Disagreements in transcribing were resolved through discussion until $100 \%$ agreement was reached by the first author and the linguist. The second author has a background in speech-language pathology and expertise in first and second language development, phonetics, and phonology. The first and second authors worked together to code the transcripts for phonological processes used by the Hong Kong participants. The authors resolved disagreements through discussion until 100\% agreement was reached.

For purposes of analysis, all words were transcribed according to American English pronunciations by the second author. Use of either RP or American English was deemed appropriate. See Appendix A for a list of words and transcriptions in RP and American English.

\section{Results}

The data were analyzed descriptively. Initial analysis of the raw data across participants indicated the majority of phonological simplifying processes occurred on one and two syllable words (169 deviations vs. 174 deviations, respectively). The number of phonological processes occurring on three syllable words was noticeably 
less (123 deviations). When corrected for the number of possible occurrences across all words, the number of deviations per single word (total deviations divided by the number of word occurrences) was as follows: single syllable words $=9.94$ deviations; two syllable words $=14.5$ deviations; three syllable words $=11.18$ deviations. Two syllable words presented the most difficulty, followed by three and single syllable words. A total of 466 phonological process deviations were noted for the 37 participants. The raw data also indicated a high number of vowel substitutions. Refer to Table 3.

Table 3

Phonological Processes: Syllable Length of Stimulus Items and Occurrences across Items

\begin{tabular}{|c|c|c|c|c|}
\hline $\begin{array}{l}\text { Phonological } \\
\text { Process }\end{array}$ & $\begin{array}{l}\text { One Syllable } \\
\text { Words }\end{array}$ & $\begin{array}{l}\text { Two Syllable } \\
\text { Words }\end{array}$ & $\begin{array}{l}\text { Three Syllable } \\
\text { Words }\end{array}$ & Total \\
\hline Fronting * & 30 & 46 & 1 & 77 \\
\hline Stopping * & 8 & 0 & 0 & 8 \\
\hline Backing & 16 & 2 & 5 & 23 \\
\hline Deaffrication * & 0 & 1 & 0 & 1 \\
\hline Affrication & 1 & 9 & 0 & 10 \\
\hline Gliding * & 7 & 3 & 7 & 17 \\
\hline Devoicing * & 3 & 14 & 0 & 17 \\
\hline Voicing & 1 & 13 & 1 & 15 \\
\hline Lip Rounding * & 7 & 3 & 7 & 17 \\
\hline $\begin{array}{l}\text { Pre-vocalic } \\
\text { Singleton } \\
\text { Omission }\end{array}$ & 4 & 1 & 0 & 5 \\
\hline $\begin{array}{l}\text { Post-vocalic } \\
\text { Singleton } \\
\text { Omission }\end{array}$ & 3 & 2 & 7 & 12 \\
\hline $\begin{array}{l}\text { Consonant } \\
\text { Sequence } \\
\text { Reduction }\end{array}$ & 1 & 12 & 9 & 22 \\
\hline $\begin{array}{l}\text { Vowel } \\
\text { Deviations }\end{array}$ & 88 & 64 & 83 & 235 \\
\hline Total & 169 & 170 & 120 & 459 \\
\hline
\end{tabular}

* Chan and Li (2000);Hung (2000); Shibbard (2004) 
The raw data were corrected for the number of occurrences among the 40 stimulus items and for the total number of occurrences in the pronunciation of the items by participants. Table 4 illustrates the raw occurrences (uncorrected), the number of phonological processes occurring across the stimulus items, the percentage of occurrence (POC) deviations for the phonological processes (raw occurrences divided by number of occurrences in stimulus items), and the POC ranking for the 13phonological processes as seen in this sampling of English spoken by Hong Kong teachers.The ranking and POC deviations for the Cantoneseinfluenced deviations from RP and American English were as follows:

(1) Gliding (15.32\%); substitution of a glide / w, j/ for a liquid or fricative (Nicolosi, Harryman, \& Kresheck 2004); e.g., /'vedztəbəl/ (vegetable) ->/'wedztəbəl/.

(2) Lip rounding $(15.32 \%)$; rounding the lips so /v/ is pronounced as /w/; e.g., /'vedłtəbəl/ (vegetable) ->/'wedłtəbəl/.

(3) Vowel deviations $(8.25 \%)$; / I/ for /i/, /i/ for /I/, /eI/ for /I/, /e/ for /æ/, /e/ for $/$ eI/, /əv/ for $/ \partial /, / a /$ for $/ \partial /$ and other schwa deviations.

(4) Cluster reduction $(4.25 \%)$; consonant clusters or blends reduced to a single consonant, or both consonants are totally omitted (Lahey, 1988); e.g., as / pl/ -> / p/, /'plezə/ (pleasure)-> /'pezə/.

(5) Fronting (2.22\%); replacing posterior consonants with anterior consonants

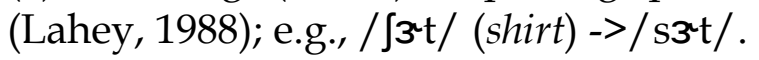

(6) Affrication (1.69\%); a fricative is replaced with an affricative (Nicolosi, Harryman, \& Kresheck, 2004); e.g., / mo'staJ/ (moustache) -> /mo'stat J/.

(7) Devoicing (1.58\%); substituting a voiceless consonant for a voiced consonant (Nicolosi, Harryman, \& Kresheck 2004); e.g., /'plezə/ (pleasure)->/'plejə/.

(8) Post-vocalic singleton omission $(1.30 \%)$; omission of a single consonant following a vowel in the same syllable; e.g., / Jod/ (should) $->/ \int \mho /$.

(9) Stopping (0.87\%); substituting fricatives with stops (Nicolosi, Harryman, \& Kresheck 2004); e.g., / diz/ (these) -> /diz/.

(10) Voicing (0.76\%); substituting a voiced consonant for a voiceless consonant (Nicolosi, Harryman, \& Kresheck 2004); /'pıefə/ (pressure)-> /'pıezə/.

(11) Backing (0.56\%); substitution of an anterior consonant with a posterior

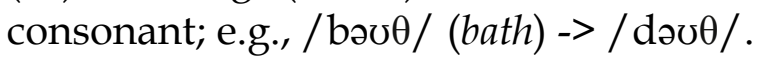

(12) Pre-vocalic singleton omission $0.55 \%$; omission of a single consonant preceding a vowel in the same syllable; /bəv $\theta /$ (bath) $->/$ /ə $\theta /$. 
(13) Deaffrication $0.45 \%$; an affricate is replaced by a fricative; /kə'ıeldzəs/ (courageous) -> / kə'ıelJəs/.

The total POC deviations for this sample were 53.12\%, indicating that over half of the participant responses contained some deviation from RP and/or American English phonology. See Table 4.

Table 4

Phonological Processes: Percentage of Occurrence Deviations and Frequency of Deviations among Participant Responses

\begin{tabular}{|c|c|c|c|c|c|c|c|}
\hline $\begin{array}{l}\text { Phonological } \\
\text { Process }\end{array}$ & $\begin{array}{l}\text { Raw } \\
\text { Occurrences } \\
\text { among } \\
\text { Participants }\end{array}$ & $\begin{array}{l}\text { Number of } \\
\text { Occurrences } \\
\text { in Stimulus } \\
\text { Items }\end{array}$ & $\begin{array}{l}\text { Number of } \\
\text { Occurrences } \\
\text { in Stimulus } \\
\text { Items X } \\
\text { Number of } \\
\text { Participants } \\
(\mathrm{n}=37)\end{array}$ & $\begin{array}{l}\text { Percentage } \\
\text { of } \\
\text { Occurrence } \\
\text { (POC) } \\
\text { Deviations }\end{array}$ & $\begin{array}{l}\text { POC } \\
\text { Ranking }\end{array}$ & $\begin{array}{l}\text { Frequency } \\
\text { of } \\
\text { Deviations }\end{array}$ & $\begin{array}{l}\text { Percentage } \\
\text { of Total } \\
\text { Deviations }\end{array}$ \\
\hline $\begin{array}{l}\text { Vowel } \\
\text { Deviation }\end{array}$ & 235 & 77 & 2849 & $8.25 \%$ & 2 & $235 / 459$ & $51 \%$ \\
\hline Fronting & 77 & 94 & 3478 & $2.22 \%$ & 4 & $77 / 459$ & $16 \%$ \\
\hline Backing & 23 & 111 & 4107 & $0.56 \%$ & 10 & $23 / 459$ & $5 \%$ \\
\hline $\begin{array}{l}\text { Cluster } \\
\text { Reduction }\end{array}$ & 22 & 14 & 518 & $4.25 \%$ & 3 & $22 / 459$ & $5 \%$ \\
\hline Gliding & 17 & 3 & 111 & $15.32 \%$ & 1 & $17 / 459$ & $4 \%$ \\
\hline Devoicing & 17 & 29 & 1073 & $1.58 \%$ & 6 & $17 / 459$ & $4 \%$ \\
\hline $\begin{array}{l}\text { Lip } \\
\text { Rounding }\end{array}$ & 17 & 3 & 111 & $15.32 \%$ & 1 & $17 / 459$ & $4 \%$ \\
\hline Voicing & 15 & 53 & 1961 & $0.76 \%$ & 9 & $15 / 459$ & $3 \%$ \\
\hline $\begin{array}{l}\text { Post-Voc. } \\
\text { Sing. Om. }\end{array}$ & 12 & 25 & 925 & $1.30 \%$ & 7 & $12 / 459$ & $3 \%$ \\
\hline Affrication & 10 & 16 & 592 & $1.69 \%$ & 5 & $10 / 459$ & $2 \%$ \\
\hline Stopping & 8 & 25 & 925 & $0.87 \%$ & 8 & $8 / 459$ & $2 \%$ \\
\hline
\end{tabular}




\begin{tabular}{|l|l|l|l|l|l|l|l|}
\hline $\begin{array}{l}\text { Pre-Voc. } \\
\text { Sing. Om }\end{array}$ & 5 & 25 & 925 & $0.55 \%$ & 11 & $5 / 459$ & $1 \%$ \\
\hline Deaffrication & 1 & 6 & 222 & $0.45 \%$ & 12 & $1 / 459$ & \\
\hline Total & 459 & 481 & 17797 & $53.12 \%$ & & $459 / 459$ & $100 \%$ \\
\hline
\end{tabular}

\section{Discussion}

The results indicated that this group of Cantonese-English speaking participants displayed a wide variety of articulatory patterns not evidenced by the literature. Most deviations occurred on two syllable words, followed by three and then single syllable words. The data also indicated a high number of vowel substitutions across words, which would affect listener intelligibility. All affected consonant deviations as noted by Chan and Li (2000), Hung (2000) and Shibbard (2004) were noted in this sample. One third of the specific articulation deviations (Chan \& Li, 2000; Hung, 2000; Shibbard, 2004) were also found in this study; however, additional deviations were noted to include the following consonants: / p, t, d, k, s, m, l, ds/ and consonant clusters / pr, br, gr, pl, st, kj, sj/.

Differences among what was found in the noted literature and in this sample are most probably accounted for by differences in population samples, the instrument, and the inventory of words elicited. It appears the PTCSE developed by the authors of this study as a phonology instrument, due to the fact that more deviations were found, was most likely more robust than what was used by Chan and $\mathrm{Li}$ (2000), Hung (2000) and Shibbard (2004). More vowel deviations were also noted in this study. Chan and Li (2000), Hensman (1969), Hung (2000), Ruikuo (2005), So and Dodd (1995), and So and Zhou (1998) found the following vowels to be affected in articulation: /I, u, a, i, ae, o, o/. In addition to what the literature has found, the following additional single (monothong) vowels and diphthong vowels varied in pronunciation in this study: /av, eI, $\mathrm{p}, 3, \varepsilon$, əv, $\Lambda$ /.Different sample populations and different eliciting instruments most likely contributed to the differences in results from the research and literature.

Six phonological processes were noted in previous studies: (a) stopping; (b) fronting; (c) deaffrication; (d) gliding; (e) devoicing; and (f) lip rounding (Chan \& $\mathrm{Li}$, 2000; Hung, 2000; Shibbard, 2004). Phonological processes noted in this study included: (a) stopping; (b) fronting; (c) deaffrication; (d) gliding; (e) devoicing; (f) lip rounding; (g) backing; (h) affrication; (i) voicing; (j) pre-vocalic singleton omission; (k) post-vocalic singleton omission; (l) cluster reduction; and, (m) vowel deviations. The most frequent phonological deviations from this study included: (a) gliding $(15.32 \%)$; (b) lip rounding $(15.32 \%)$; (c) vowel deviation (8.25\%); (d) cluster reduction $(4.25 \%)$; (e) fronting (2.22\%); and (f) affrication (1.69\%). Again, it is believed population samples and the elicitation sample affected the results from this study, which seemed to be more comprehensive.

Although the studies by Chan and Li (2000), Hung (2000), and Shibbard (2004) were relatively recent and sampled Hong Kong Cantonese speakers, these 
studies do not directly assess phonological processes, but rather list substitution

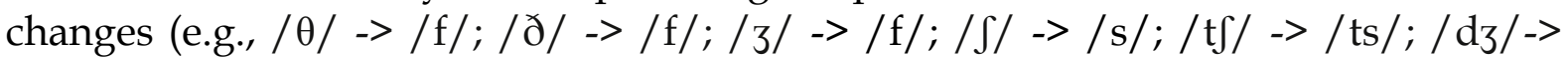
$/ \mathrm{dz} /)$. The authors of this study inferred the phonological processes affected by these phonetic substitution changes in the Hung (2000) and Shibbard (2004) studies. Chan and Li (2000) stated they found the phonological processes of substitution, deletion, and epenthesis in their population of Cantonese speakers; however, it should be noted that these were simply observations and did not include any systematic phonological process data collection and analysis.

It would be helpful for future research to use the language of phonological processes in data analysis as a whole set of sounds can be affected by one process. It is evident from this study and the literature that Cantonese speakers change tongue placement (with regards to fronting) when speaking English. In addition, the speakers in this study also changed articulation with regards to voicing and manner distinctions. Further research is needed in the articulation and phonological patterns of Cantonese-English speakers as this research is still very limited.

This study was unable to identify the source of the misarticulations and phonological deviations. The authors propose that a combination of factors could have influenced the participants' speech, i.e., Cantonese interference, lack of knowledge of English phonological constraints, logographic writing background, and the influence of RP vs. American English dialects spoken in Hong Kong. It was noted the participants in this study consistently misarticulated several words. For example, the words pilot and photograph were consistently pronounced emphasizing a long 'o' sound, and passage was pronounced with a long 'a' sound as in 'age'. These long vowel sounds were substituted for the schwa, and the words were pronounced as they appear in print. Further research can identify the vowels that Cantonese speakers substitute for schwas in multisyllabic words to see if there are any patterns to the vowel substitutions.

The Cantonese-English speakers from this study demonstrate certain articulatory and phonological differences when compared to RP and American English patterns. Chan and Li (2000:83) stated, "Teachers should also determine the relative gravity of various pronunciation errors and set up a system of teaching priorities". We agree with Chan and $\mathrm{Li}$ (2000) in recommending teachers identify misarticulations that affect understanding and introduce specific teaching strategies that focus on articulation of these sounds.

According to the motor theory of speech production (Liberman \& Mattingly, 1985), perception of speech sounds occurs when an individual is able to identify a particular sound using the same processes for production, i.e., perception of sounds is tied to its production. Hence, perception and production are interrelated and intertwined; therefore, any exercise in articulation and speech production should also involve correct perception of sounds. Students should be exposed to correct speech models and also should engage in specific production exercises.In addition, we suggest teachers incorporate strategies that address place, manner, and voicing articulation changes for specific sounds and specific phonological processes. If Cantonese learners of English wish to modify and change their pronunciation to more closely resemble the English spoken by native English speakers (e.g., RP or 
American English), we recommend the following teaching priorities with regard to the results from this study.

1. Vowels. A substantial number of vowels were affected. Vowels are known to highly influence intelligibility; therefore, teachers should carefully articulate all words emphasizing vowels, modeling RP or American English production. Since Cantonese does not have the schwa sound, teachers may explicitly introduce this sound to students and provide examples and sufficient practice for students to understand the articulation and occurrence of schwas in English multisyllabic words. Students can monitor their own vowel production and imitate the teacher's production. Single vowels can be practiced and attained before diphthong vowels are attempted. Use of a mirror along with a vowel chart indicating front-back and high-low tongue placement is suggested.

2. Fronting.This phonological process deviation is most likely influenced from Cantonese. Students should make a conscious effort to monitor their tongue placement and to listen to the teacher model. The teacher may implement use of a consonant chart indicating tongue placement. In addition, students may use mirrors when practicing correct placement and articulation of certain consonant sounds.

3. Voicing/devoicing.Students may monitor voicing or voiceless sound productions for stop and fricative consonants (i.e., all obstruent sounds). The teacher may also introduce a consonant chart indicating voiced and voiceless consonant sounds. Students may monitor their production of voiced vs. voiceless sounds by placing their fingers on the exterior of their larynx (i.e., throat).

4.Omissions.Omission or pre-vocalic and post-vocalic singleton consonants posed difficulty for the Cantonese-English speakers. Monitoring articulation of consonant sounds before and after vowels along with careful listening to RP or American English models is essential. American or RP articulation and production of pre-vocalic and post-vocalic consonant sounds can be enhanced by practicing with short single syllable CVC words (e.g., hat, pat) and then proceeding to longer multisyllabic words (e.g., library, constitutional).

5. Cluster reductions. Consonant clusters and blends posed difficulty for the Cantonese-English speakers. This seems to be a feature of Cantonese interference as few consonant sequences and blends exist in Cantonese. It is suggested that speakers listen to RP or American English models, monitor, and make conscious efforts at RP or American English articulation. Correct production of consonant clusters should begin with articulation exercises consisting of only the consonant cluster (e.g., 'sp', 'st', etc.). Also, students can pronounce the first consonant of a cluster alone and then blend the second consonant to the first. The teacher and students should initially avoid consonants that are problematic for Cantonese-English speakers (e.g., / J $)$.

6. Liquid ( $\mathrm{r} / \mathrm{l}$ ) distinctions. It has been cited in the literature (Chan \& Li, 2000; Hung 200) and verified by our study that the Cantonese-English speakers experienced difficulties producing the $/ \mathrm{V}$ sound. It is recommended that students practice saying this sound in isolation before attempting single syllable and multisyllabic words. Practice should be given then to single syllable words and words containing this sound in the initial position. Students can practice pronouncing common words with / $V /$ and /1/ sounds, such as right, ring, red, room 
and look, last, let, low, and one syllable words in minimal pairs, such as lip/rip, led/red, lane/rain, lot/rot.

The above strategies also apply to pre-service teachers in their education. It is recommended these phonological process strategies be introduced into appropriate coursework. At our university these strategies are taught in a class for all teachers seeking endorsement to teach English to speakers of other languages (ESOL), i.e., Language Principles and Acquisition. It may also be taught in other similar type courses.

In conclusion, this study found numerous examples of English articulatory and phonological differences in the speech of Cantonese-English speakers through the administration of the Phonology Test for Cantonese Speakers of English (PTCSE).The PTCSE appears to be a reliable and valid instrument for assessing English articulation and phonology skills of Cantonese speakers of English. It is crucial that further studies validate these findings and contribute to a better understanding of Cantonese influenced English as evidenced in Hong Kong speech. 


\section{References}

Chan, A., \& Li, D. (2000). English and Cantonese phonology in contrast: Explaining Cantonese ESL learner's English pronunciation. Language, Culture and Curriculum, 13(1), 67-85.

Chen, X., Anderson, R.C., Li, W., Hao, M., Wu, X., \& Shu, H. (2004). Phonological awareness of bilingual and monolingual Chinese children. Journal of Educational Psychology, 96(1), 142-151.

Cohen, J. (1988). Statistical power analysis for the behavioral sciences (2nd ed.). Hillsdale, NJ: Lawrence Erlbaum.

Crocker, L., \& Algina, J. (1986). Introduction to classical and modern test theory.New York: CBS College Publishing.

Hensman, B. (1969). The phonological problems of Chinese students of English as a second language. Studium, 2, 197-210.

Hung, T. T. N. (2002). Towards a phonology of Hong Kong English. In K. Bolton (Ed.),Hong Kong English: Autonomy and creativity (pp. 119-140). Hong Kong: Hong Kong University Press. Reprinted from Hung, T. T. N. (2000). Towards a phonology of Hong Kong English. World Englishes, 19(3), 337-356.

Interagency Language Round table. (2010). Interagency language roundtable language skill level descriptions: Speaking. Retrieved from http:/ / www.govtilr.org/Skills/ILRscale2.htm\#3.

Kirkpatrick, A. (2007). World Englishes: Implications for international communication and English language teaching. Cambridge, MA: Cambridge University Press.

Lahey, M. (1988). Language disorders and language development. London: Collier Macmillan.

Law, Z. W. Y., \& So, L. K. H. (2006). Phonological abilities of hearing-impaired Cantonese-speaking children with cochlear implants or hearing aids. Journal of Speech-Language-Hearing Research, 49, 1342-1353.

Liberman, A., \& Mattingly, I. (1985). The motor theory of speech perception revised. Cognition, 21(1), 1-36.

Merkel-Piccini, R. (2001). What's news in speech! Phonological processes. Retrieved from http:/ / www.superduperinc.com/handouts/pdf/23_phonological_processes. pdf.

Nicolosi, L., Harryman, E., \& Kresheck, J. (1996). Terminology of communication disorders: Speech-language-hearing. Baltimore, MD: Williams \& Wilkins.

O'Connor, J. D. (1967). Better English pronunciation. Cambridge, MA: Cambridge University Press.

Ruikuo, G. (2005). Analysis of language borrowing between English, Chinese and Japanese. [Unpublished master's thesis]. English Department, School of Foreign Studies, Anhui University, Heifei, China.

Selinker, L., \& Lamendella, J. T. (1980). Fossilization in interlanguage learning. In K. Croft (Ed.), Reading on English as a second language (pp. 132-143.). Boston, MA: Little, Brown

Shibbard, R. (2004). The spoken English of Hong Kong: A study of co-occurring segmental errors. Language, Culture and Curriculum,17(2), 127-142.

So, L. K. H., \& Dodd, B. (1995). The acquisition of phonology by Cantonese-speaking children. Journal of Child Language, 22(3), 473-495. 
So, L. K. H., \& Zhou, J. (1998). Acquisition of Putonghua (Mandarin) phonology: Influence from the mother Tongue. Asia Pacific Journal of Speech, Language, and Hearing, 3(3), 167-168.

Wei, X. (2008). Implication of IL fossilization in second language acquisition. English Language Teaching, 1(1), 127-131.

Williamson, G. (2010). Phonological processes. Retrieved from http://www.speechtherapy-information-and-resources.com/phonological-processes.html 


\section{Appendix A}

\section{Stimulus Items}

\begin{tabular}{|c|c|c|c|c|c|c|c|c|}
\hline \multicolumn{3}{|c|}{ One Syllable Words } & \multicolumn{3}{|c|}{ Two Syllable Words } & \multicolumn{3}{|c|}{ Three Syllable Words } \\
\hline Word & $\begin{array}{l}\text { Received } \\
\text { Pronunciati } \\
\text { on }\end{array}$ & $\begin{array}{l}\text { AmericanP } \\
\text { ronunciatio } \\
\mathrm{n}\end{array}$ & Word & $\begin{array}{l}\text { Received } \\
\text { Pronuncia } \\
\text { tion }\end{array}$ & $\begin{array}{l}\text { American } \\
\text { Pronuncia } \\
\text { tion }\end{array}$ & Word & $\begin{array}{l}\text { Received } \\
\text { Pronunciation }\end{array}$ & $\begin{array}{l}\text { AmericanPron } \\
\text { unciation }\end{array}$ \\
\hline boot & /bu:t/ & /but/ & sugar & /'Juga/ & /'Juga/ & amateur & /'æmət3:1/ & /'æmэtз/ \\
\hline wheel & /wi:1/ & /wil/ & finish & /'finig/ & /'finif/ & characters & /'kærəktəz/ & /'kæıəktəz/ \\
\hline luck & $/ 1 \wedge \mathrm{k} /$ & $/ 1 \wedge \mathrm{k} /$ & village & /'vilidz/ & /'vilıdz/ & preferable & /'p」efrəbəl/ & /'pıefıəbəl/ \\
\hline should & $/ \int u d /$ & / $u d /$ & method & /'me日əd/ & /'me日əd/ & utility & /ju:'ıliti/ & /ju'tılıti/ \\
\hline these & /ði:z/ & /ðiz/ & perhaps & /pə'hæps/ & /pə'hæps/ & explosion & /Ik'spləひZən/ & /ık'spləひzən/ \\
\hline chance & /tfa:ns/ & /tfans/ & chauffeur & 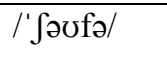 & /'Səufa/ & biography & /bai'ng」əfi/ & /baı'gıəfi/ \\
\hline \multicolumn{3}{|c|}{ One Syllable Words } & \multicolumn{3}{|c|}{ Two Syllable Words } & \multicolumn{3}{|c|}{ Three Syllable Words } \\
\hline Word & $\begin{array}{l}\text { Received } \\
\text { Pronuncia } \\
\text { tion }\end{array}$ & $\begin{array}{l}\text { AmericanP } \\
\text { ronunciatio } \\
\mathrm{n}\end{array}$ & Word & $\begin{array}{l}\text { Received } \\
\text { Pronunci } \\
\text { ation }\end{array}$ & $\begin{array}{l}\text { AmericanP } \\
\text { ronunciatio } \\
n\end{array}$ & Word & $\begin{array}{l}\text { Received } \\
\text { Pronunciation }\end{array}$ & $\begin{array}{l}\text { AmericanPro } \\
\text { nunciation }\end{array}$ \\
\hline bed & /b3:d/ & /bзed/ & pilot & /'pailət/ & /'pailət/ & courageous & /kə'reIdzos/ & /kə'ıеıdzəs/ \\
\hline made & /meid/ & /meıd/ & mustache & /mo'sta: & /mə'staj/ & photograph & /'fəutəgra:f/ & /'fəðtəgıаf/ \\
\hline round & /raond/ & /ıarnd/ & journey & /'dz3:ni/ & /'dł3゙ni/ & curiosity & /kjuərı' nsəti/ & /kjбәдı'osəti/ \\
\hline shirt & $/ \sqrt{3}: \mathrm{t} /$ & $/ \int 3 \mathrm{t} /$ & passage & /'pæsıdz/ & /'pæsidz/ & peninsula & /pə'ninsjulə/ & /pə'nınsjolə \\
\hline both & /bəv日/ & 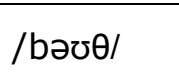 & pleasure & /'plezə/ & /'plezə/ & vegetable & /'veḑtəbəl/ & /'vedztəbəl/ \\
\hline $\operatorname{van}$ & /væn/ & /væn/ & pressure & /'pגefə/ & /'pдefә/ & & & \\
\hline soup & /su:p/ & /sup/ & & & & & & \\
\hline than & /ðæn/ & /ðæn/ & & & & & & \\
\hline \multicolumn{3}{|c|}{ One Syllable Words } & \multicolumn{3}{|c|}{ Two Syllable Words } & \multicolumn{3}{|c|}{ Three Syllable Words } \\
\hline Word & $\begin{array}{l}\text { Received } \\
\text { Pronuncia } \\
\text { tion }\end{array}$ & $\begin{array}{l}\text { AmericanP } \\
\text { ronunciatio } \\
n\end{array}$ & Word & $\begin{array}{l}\text { Received } \\
\text { Pronuncia } \\
\text { tion }\end{array}$ & $\begin{array}{l}\text { American } \\
\text { Pronuncia } \\
\text { tion }\end{array}$ & Word & $\begin{array}{l}\text { Received } \\
\text { Pronunciation }\end{array}$ & $\begin{array}{l}\text { AmericanPron } \\
\text { unciation }\end{array}$ \\
\hline bread & /b」ed/ & /bJed/ & & & & & & \\
\hline
\end{tabular}




\begin{tabular}{|l|l|l|l|l|l|l|l|l|}
\hline name & /nerm/ & $/$ nerm/ & & & & & & \\
\hline walk & /wo:k/ & /wok/ & & & & & & \\
\hline
\end{tabular}


Appendix B

Phonology Test for Cantonese Speakers of English (PTCSE)

Phonology Test for Cantonese Speakers of English (PTCSE) Leung and Brice (2011)

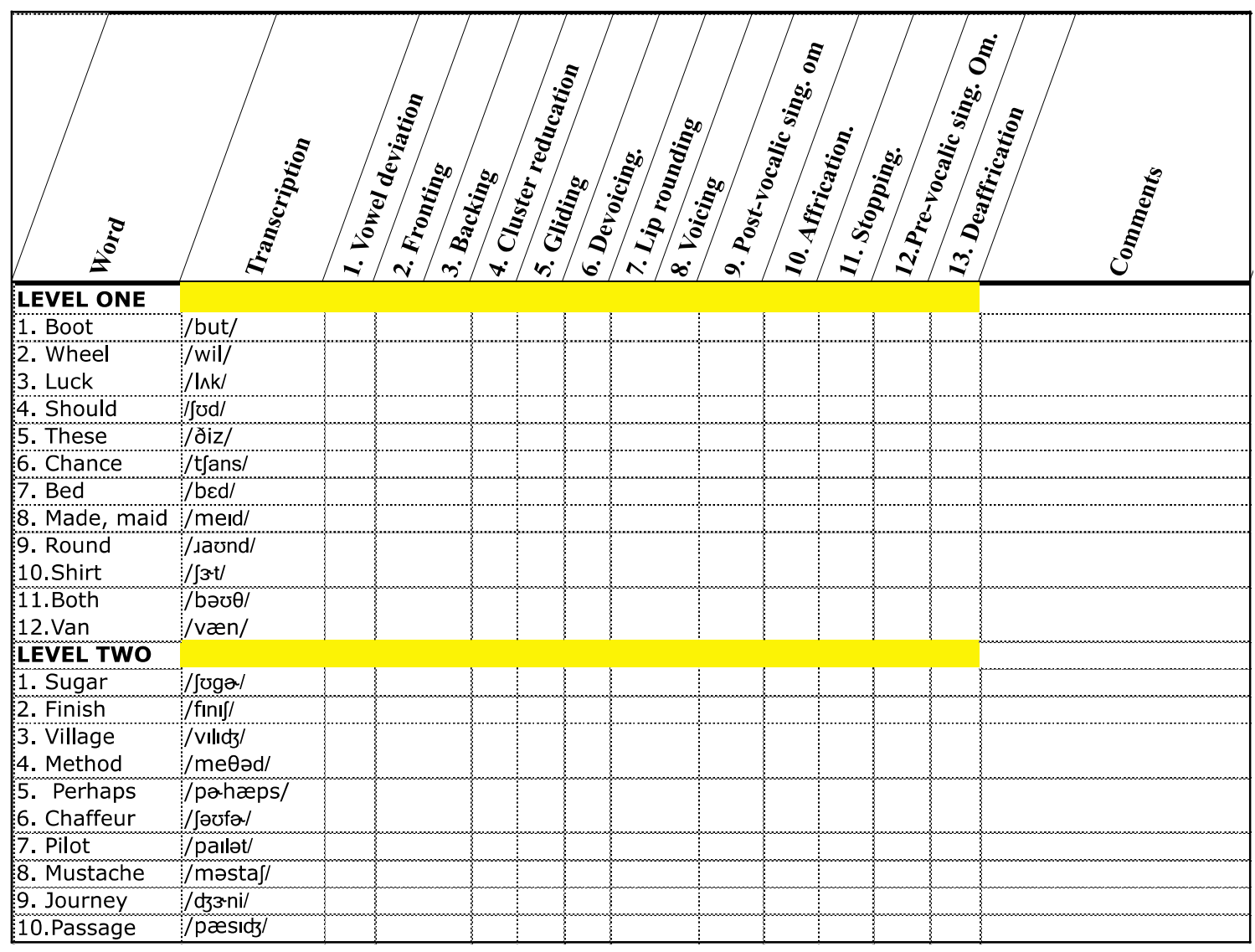

Phonology Test for Cantonese Speakers of English (PTCSE) Leung and Brice (2011)

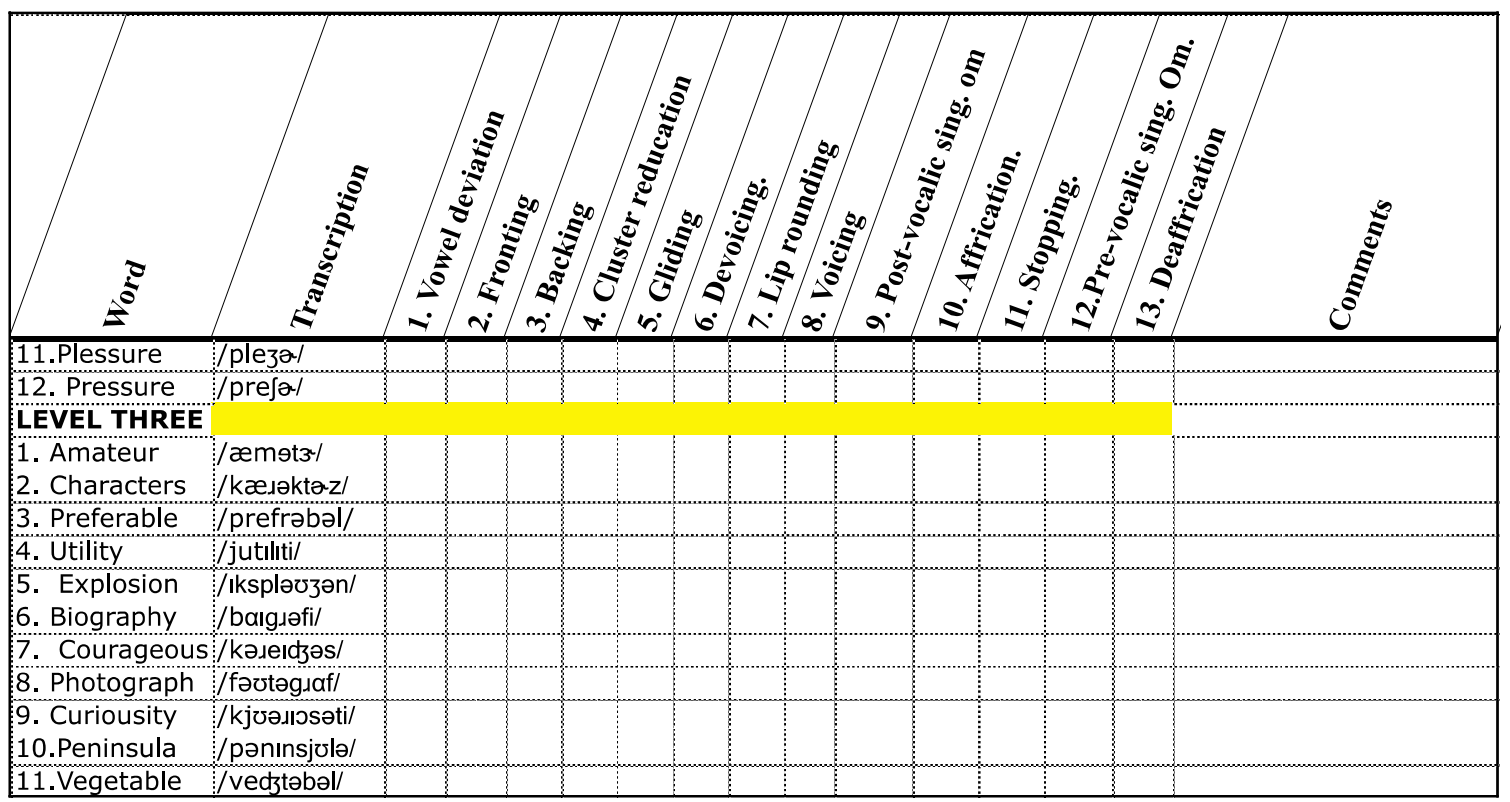

